\title{
Digital technology and changing roles: a management accountant's dream or nightmare?
}

\author{
Roy-Ivar Andreassen ${ }^{1}$ (D)
}

Published online: 27 July 2020

(C) The Author(s) 2020

\begin{abstract}
Recent developments in digital technology have revitalized interest in the relationship between technology and management accounting. Yet, few empirical in-depth studies have assessed how digital technologies influence the roles of management accountants. This paper builds on the concept of jurisdiction to illuminate the relationship between management accountants, expert knowledge and digital technology. The study identifies and describes competition over jurisdiction between management accountants and other groups of employees. The study describes a shift for divisional management accountants towards narrower roles in their tasks and expectations, while business-oriented roles at group level are found to entail expanding tasks and expectations. In doing so, management accountants are divided into two divergent categories facing different expectations: divisional and group level management accountants. Through a case study in the technology-oriented finance sector, the paper contributes to the debate on the roles of management accountants in a number of ways. First, it describes how digital technology can contribute to narrower and more specialized roles. Second, it describes how digital technology can contribute to competition between professions. Third, it elucidates how digital technology contributes to changes in the behaviour of decision makers, and in their expectations toward, and the involvement of, management accountants. Fourth, it details how the changes contributed by digital technology in the roles of management accountants can act as mediators in the identity-work of management accountants. Finally, it empirically describes the relationships between digital technology and management accountants' roles.
\end{abstract}

Keywords Digitalization · big data $\cdot$ machine learning $\cdot$ Management accountants role $\cdot$ Controller role

Roy-Ivar Andreassen

roy.i.andreassen@ntnu.no

1 NTNU Business School, Norwegian University of Science and Technology, 7491 Trondheim, Norway 


\section{Introduction}

I think digitalization plays a role in this [the tasks of management accountants]; we can always apply new tools to automate, do things more effectively. While I think, at least as I see it in our function, it is about structuring data, structuring data sources. And in a way doing everything [in a] more unified [way so as] to be able to work with the data more easily, and in this area, I think digitalization is really, really good, it is important. But the actual use, more into machine learning and artificial intelligence, I think there is still a way to go before it takes over a management accounting role, for that requires users-or, luckily, at least currently it does. (Group-level management accountant).

Among practitioners there is increasing interest in how digital technology contributes to changing the roles of management accountants (Accenture 2018; Eklund et al. 2018; McCorkell and Shapiro 2016). The literature has predicted that automation and increased use of digital technology will have major consequences for a number of professions (Frey and Osborne 2017); in addition, the roles of management accountants are expected to be impacted by these consequences (Appelbaum et al. 2017; Bhimani and Willcocks 2014; Moll and Yigitbasioglu 2019; Quattrone 2016). The present study explores this important yet understudied relationship between digital technology and the roles of management accountants.

The ways in which digital technology may affect management accountants has been problematized in the literature (see Järvenpää 2007; Quattrone 2016; Suddaby et al. 2015). Quattrone (2016) raised concerns regarding a potential reversal of the business orientation of management accountants, where the technology contributes to management accountants returning to focusing on quantitative measurements that are removed from business operations. Historically, accounting practices have contributed to nuance in the interpretation of numbers, while data-driven decision makers contrastingly treat numbers as representing absolute truths (Quattrone (2016).

To understand how technology influences the professional roles of management accountants, this paper builds on the concepts of jurisdiction of expert labour groups (Abbott 1988), identity (Brown 2019) and social role theory (Biddle 1986). To illuminate the interaction between digital technology and the role of management accountants, the paper addresses the following research question: How do digital technologies contribute to changes in the roles and jurisdiction of management accountants?

To explore such role changes, this paper investigates InsuranceCo, ${ }^{1}$ a Nordic insurance company operating in the technologically advanced finance sector. The company has several highly educated statisticians, mathematicians, engineers and management accountants involved in the adaptation of integrated information systems, big data and machine learning. The number of PhDs, and especially

${ }^{1}$ A pseudonym. 
the number of statisticians, in the company and the industry differentiate it from other firms and sectors. This appears highly relevant for studying the adaptation of machine learning, which is closely related to statistical knowledge since machine learning requires statistical knowledge to prepare data, select statistical methods for machine learning models and interpret the predictive models.

This study contributes to the management accounting literature in a number of ways. First, it explores how digital technology contributes to changes in the roles of management accountants and how digital technology can contribute to narrower and more specialized roles nuancing descriptions of expanding and broader roles (Goretzki and Messner 2019; Holmgren Caicedo et al. 2018; Horton and Wanderley 2018; Rieg 2018). Second, by taking a perspective based on competition of professions (Abbott 1988) the study finds that digital technology influences intra-organizational competition between professions and thus contributes to changes in management accountant roles. Third, it finds that digital technology not only contributes to changes in roles as tasks of management accountants (Burns and Baldvinsdottir 2005; Rieg 2018; Weber 2011). Drawing on social role theory(Biddle 1986; Järventie-Thesleff and Tienari 2016; Simpson and Carroll 2008; Sveningsson and Alvesson 2003) the findings show that digital technology also contributes to wider and broader changes beyond tasks in management accountants' roles. Fourth, it builds on theories of roles as mediators in identity-work (Järventie-Thesleff and Tienari 2016) and finds that digital technology contributes to changes in management accountant roles which in turn influence the identity-work of management accountants. Lastly, the study provides an empirical description of the relationship between digital technology and management accountant roles and jurisdiction.

The remainder of this paper is structured as follows. Section 2 discusses existing literature on the relationship between digital technology and management accounting, and the roles of management accountants and theories of jurisdiction, identity and social role theory. Section 3 describes the research methods; Sect. 4 presents the case; Sect. 5 analyses the case; and Sect. 6 discusses this analysis and its theoretical implications. Finally, Sect. 7 concludes the paper.

\section{Theoretical background}

\subsection{Digital technology and management accounting}

Digital technology has become a topic of considerable interest (Accenture 2018; AlHtaybat and von Alberti-Alhtaybat 2017; Bhimani and Willcocks 2014; McCorkell and Shapiro 2016; Quattrone 2016). To make the broad topic of digitalization and digital technologies more tangible, this paper conceptualizes them as concepts consisting of several elements, of which the paper addresses integrated information systems, big data and machine learning.

While integrated information systems have been described as information systems sharing a common database (Rom and Rohde 2007), the contemporary understanding adopted in this paper is that integrated information systems are information systems that incorporate exchange of data at a defined frequency between one another. 
Big data in this paper refers to the increasing volume of data that is generated and accessible. However, it not only refers to an increase in the amount of data, but also to increases in velocity (timely updates) and variability (types of data), which are two other fundamental dimensions defining big data (Gandomi and Haider 2015).

Machine learning represents the applied use of algorithms and statistical models by computer systems to progressively improve their performance on specific tasks (Murphy 2012). It is closely related to theories of statistical learning (James et al. 2013), where computer systems find predictive functions that fit the data. The computer systems then evaluate the functions and select those that provide the most accurate predictions, thereby creating models that consist of a high number of functions. These mathematical and statistical functions can be thought of and illustrated as decision trees, where each node represents a separate function, creating different paths the data can follow or be grouped into create the most accurate prediction. As the amount of data generated increases exponentially (World Bank 2016) and computing power improves, this enhances the ability of computer systems to find patterns and significant correlations between variables.

In management and organizational studies of technology, there has been a dominance of research conceptualizing technology as having generalizable and unidirectional effects at a macro level. This literature, which takes a positivistic perspective, conceptualizes technology as an "external force that would have (relatively) deterministic impacts on organizational properties such as structure" Orlikowski (1992 p. 399). Similar to the management and organizational literature, several studies in management accounting have adopted positivistic approaches to technology, resulting in deterministic studies of technology dominating the field (Rikhardsson and Yigitbasioglu 2018; Rom and Rohde 2007). Consequently, a number of studies have sought to establish causal impacts of introducing technology in management accounting (Kallunki et al. 2011; Rom and Rohde 2007). Despite the dominance of this view, however, other theoretical perspectives have also been applied to technology and management accounting. Such alternative approaches have included contingency approaches (Byrne and Pierce 2007; Chapman and Kihn 2009; Chenhall 2003), structuration theory (Caglio 2003) and actor network theory (Dechow and Mouritsen 2005). These studies do not claim the effects from technology to be deterministic, nor that the impacts are applicable to all organizations. The current study seeks to engage in this stream of non-deterministic debate on how digital technology can contribute to changes in management accounting.

Quattrone (2016) addressed the importance of accountant practices and the role of accountants as interpreters of numbers, describing numbers as imperfect depictions and representations that are open to interpretation and discretionary judgements. The accounting interpretation of numbers stands in contrast to the increase in data-driven decisions based on algorithms and machine learning. Data-driven decisions treat numbers not as imperfect sets of information but as containing all relevant information (McAfee and Brynjolfsson 2012; Quattrone 2016). Data-driven decisions are portrayed as promising faster and more objective decisions, while Quattrone (2016) raised concerns that this will narrow the role of accounting, specifically the role accounting plays in enabling and contributing to discussions and interpretations of data. 


\subsection{The roles of management accountants and the accountancy profession}

The roles of management accountants have been researched intensively in recent decades (Burns and Baldvinsdottir 2005; Byrne and Pierce 2007; Granlund and Lukka 1998; Weber 2011) and it remains an ongoing area of research (Goretzki et al. 2017; Goretzki et al. 2013; Holmgren Caicedo et al. 2018; Moll and Yigitbasioglu 2019; Rieg 2018; Schäffer and Brückner 2019). A number of these studies have adopted an understanding of accounting as a social practice that provides legitimacy and supporting claims of rationality (Miller and Hopwood 1994), rather than a functionalist perspective. In this stream of research, Suddaby et al. (2015) described how objective measures are valuable in an increasingly rationalized society.

The research on management accountant roles has focused on the tasks of management accountants. For example, Goretzki et al. (2013), Burns and Baldvinsdottir (2005), Rieg (2018) and Weber (2011) have illustrated the close connection between tasks and the theorization of management accountant roles.

Roles have been categorized into two stereotypes: bean-counters and business partners (Byrne and Pierce 2007; Friedman and Lyne 2001; Järvenpää 2007; Rieg 2018; Wolf et al. 2015). Where bean-counters are focused on practical tasks such as measuring and keeping accounts, business partners are involved in decision making and strategic tasks. Other roles that have been described include information experts, methodology experts and gatekeepers (Burns and Baldvinsdottir 2005; Byrne and Pierce 2007; Granlund and Malmi 2002; Scapens and Jazayeri 2003; Schaltegger and Zvezdov 2015).

The expanding roles of management accountants are closely related to what the literature describes as business-oriented partner roles (Burns and Baldvinsdottir 2005; Goretzki and Messner 2019; Goretzki et al. 2013; Järvenpää 2007). The increasing business orientation has been promoted by peers, top management, and education and professional bodies, as managerial tasks and involvement in strategy and general decision making have been presented as rational objectives for the role (Burns and Baldvinsdottir 2005; Goretzki and Messner 2019).

Studies exploring the relationship between technology and the roles of management accountants have also indicated a broader and expanding role for accountants, particularly management accountants, as a potential consequence of introducing technology (Caglio 2003; Dechow and Mouritsen 2005; Järvenpää 2007; Scapens and Jazayeri 1998; Suddaby et al. 2015). First, the repetitive accounting tasks of collating numbers and performing calculations are transferred to enterprise resource planning (ERP) systems and integrated information systems, enabling management accountants to spend more time providing assistance to decision-makers (Caglio 2003; Chapman and Kihn 2009; Dechow and Mouritsen 2005). Second, it has been theorized that ERP and IT can enable the decentralization of decisions (Caglio 2003; Dechow and Mouritsen 2005; Järvenpää 2007), increasing local decision makers' need for support from accountants as providers of information (Caglio 2003). A substantial body of literature has thus argued that digital technology contributes to an increasing business orientation and broadening of the roles of management accountants (Caglio 2003; Chapman and Kihn 2009; Dechow and Mouritsen 2005; Järvenpää 2007; 
Suddaby et al. 2015). However, broadening and expanding roles for management accountants can be at odds with the roles and identities of other professionals within organizations.

\subsection{Competition over jurisdiction}

Abbott's (1988) theory from sociology, adopted by accounting studies (Caglio 2003; Goretzki et al. 2013; Suddaby et al. 2015), conceptualizes claims and competition over jurisdiction between social groups for tasks and influence. The accounting literature has drawn on the work of Abbott (1988) to address the macro-organizational level of analysis (Suddaby et al. 2015). However, a considerable part of Abbott (1988) work described and sought to address the intraorganizational "workplace" level, which has typically been labelled the meso or mid-range level of analysis in organizational and sociological studies (Fine and Hallett 2014). Abbott (1988) stated that study on this level has been lacking:

An equally important, but less studied area is the workplace. Claims made in the workplace blur and distort the official lines of legally and publicly established jurisdictions; an important problem for any profession is the reconciliation of its public and its workplace position. (Abbott 1988 p. 59-60).

Goretzki and Messner (2019) touched upon this meso level in their analysis of management accountants' identity work. Their findings indicated that the identity of management accountants is embedded in broader organizational values and concerns. There is thus an understanding of interaction between the management accountant role and other groups in organizations (see Järvenpää 2007; Kurunmäki 2004). The role literature in accounting has described Abbott's (1988) work as depicting competition over jurisdiction in terms of overt conflicts (Suddaby et al. 2015) and focused on how professions can claim expert knowledge to create monopolies (Cooper and Robson 2006) at a macro level. However, the analysis of accountants' role in the workplace has been identified by Goretzki et al. (2013), Suddaby et al. (2015) and Abbott (1988) as an underdeveloped area of research.

Abbott (1988) highlighted that professions constantly compete for influence and tasks. He conceptualized this as competition over jurisdiction in three different dimensions: the law, public opinion and the workplace. He described the competition between law, auditing and accounting for claiming jurisdiction over tasks, such as tax-deductible forward losses, and how historically engineering and cost accounting competed for jurisdiction over the provision of operational information to support decision-making. Cooper and Robson (2006), Kurunmäki (2004) and Johnson and Kaplan (1986) identified other examples in which engineers and accountants compete over jurisdiction to provide information and decision support. The present paper will describe how the concept of competing professions can provide a theoretical lens through which to analyse how digital technology contributes to changes in the influence and tasks of management accountants in competition with actuaries and other professions. 


\subsection{Role theory and identities}

While research on management accountant roles has broadly focused on the tasks involved therein, social role theory is a wide-ranging field within the social sciences. Role theory encompasses an array of dimensions used to define roles in society and in organizations.

Role theory concerns one of the most important characteristics of social behaviour-the fact that human beings behave in ways that are different and predictable depending on their respective social identities and the situation. As the term role suggest, the theory began life as a theatrical metaphor. (Biddle 1986 p.68).

As the role metaphor can have different interpretations, there have been a number of different descriptions and definitions of roles. Biddle (1986) highlighted that roles have been portrayed according to three groups of interpretations: characteristic behaviour, social parts to be played or scripts for social conduct. As roles concern social expectations of behaviour, many researchers have addressed the influence of norms in role theory, while others have assumed expectations to be either subjective beliefs or individual preferences (Biddle 1986). Practical questions regarding how different expectations from groups of others can create conflicting roles for individuals in the form of role conflict represent a topic that has been extensively researched among organizational researchers (Biddle 1986) and accounting researchers (Byrne and Pierce 2007; Goretzki et al. 2017).

Syntheses and reviews of role theory research have identified various theoretical perspectives on roles, including functional, organizational, symbolic interactionist, structural and cognitive (Biddle 1986; Järventie-Thesleff and Tienari 2016; Simpson and Carroll 2008). However, functional and organizational perspectives have provided the most extensive stream of research on managerial roles. Järventie-Thesleff and Tienari (2016) argued that the functionalist perspective has been influential in describing characteristic behaviours of individuals holding positions in social systems, while the organizational perspective has addressed "the manner in which individuals accept and enact an array of roles in task-oriented and hierarchical systems that are formal organizations." (JärventieThesleff and Tienari 2016 p.238).

As the focus of management and organizational research has shifted towards identity in recent decades (Alvesson et al. 2008), there has been a revival of research linking and exploring the relationship between roles and identity construction and identity work (Goretzki and Messner 2019; Järventie-Thesleff and Tienari 2016; Simpson and Carroll 2008). Where roles address the expectations of others, identity has been defined as "the meanings that individuals attach reflexively to themselves, which are developed and sustained through processes of social interaction as they seek to address the question 'who am I?'”(Brown 2015 p. 23). While there are different strands of literature on this topic, research interest in the description of identity has been linked to its dynamic and multi-layered properties (Alvesson et al. 2008; Brown 2019; Simpson and Carroll 2008). However, the crucial element of identity research is the self-reflexive perspective on the self within the individual. 
In this paper, role is understood from a broader perspective compared to the extant management accounting understanding of roles as tasks. This research understands the roles of management accountants in terms of expectations of behaviour patterns in the social structure within which the management accountant performs those roles. The later analysis in the paper will highlight that changes incited by digital technology are not first and foremost related to tasks but rather to behavioural patterns of decision makers. Thus, the behaviour of decision makers influences the role of management accountants and the management accountants' participation and influence in discussions of data.

\section{Research methods}

This research takes the form of an exploratory case study of InsuranceCo, a Nordic insurance and finance company. InsuranceCo was approached because it operates in the financial sector, which is one of the sectors reported to have been most impacted by digital technology. Additionally, the Nordic countries are among the leading countries with respect to digitalization (European-Commission 2016; World Bank 2016). InsuranceCo welcomed the request to grant access to the organization to perform the study and assisted in setting up interviews with relevant departments and divisions in the organization.

The data were mainly collected through interviews, but less formal meetings and document reviews were also conducted. The duration of the case study comprised a six-month period, with the first meetings and interviews conducted in late 2017, and additional interviews and visits in 2018, including informal lunches and discussions with interview subjects and their departments. A second round of interviews with three members of the executive management team was conducted in 2020 to evaluate the previous data collection and add new perspectives and information. The majority of the 14 interviews were conducted on the premises of InsuranceCo, and two were conducted via phone. The interviews lasted between $40 \mathrm{~min}$ and two hours. They were semi-structured, as the main topics were set prior to the interviews. However, there were some differences in the questions depending on the role and position of the respondent. All interviews were audio-recorded. It should also be noted that all respondents were informed that the interviews were confidential and would not be shared with InsuranceCo. They were free to withdraw from the interviews or to recall any of their statements, and in this case the withdrawal would not be shared with InsuranceCo. None of the respondents declined interviews or withdrew from the study.

The interview subjects were primarily located at head office at the group level, limiting the views from divisions. Interviews conducted at a regional office, and one interview with a divisional management accountant, were aimed at supplementing the view presented at the group level. One challenge to interviewing additional management accountants at the divisional level was that their numbers had been reduced so significantly that the largest division employed only two management accountants at the time of the study. Some divisions employed more than two management accountants; however, as it was the largest division that had reportedly taken advantage of integrated 
information systems, big data and machine learning, this division was focused on during data collection. Consequently, $50 \%$ of the management accountants in this division were interviewed. Additionally, interviews with directors from the division and informal conversations probed the roles of the divisional management accountants and the use of integrated information systems, big data and machine learning.

The research proceeded through theory, data and problem stages, which contributed to refining plausible fits between the problem, theory and data (Ahrens and Chapman 2006). Empirical data collection focused on how digital technology influences management accounting. After the initial informal meetings with InsuranceCo, the information was analysed to identify potential discrepancies between the empirical data and the management accounting literature. After conducting a first round of interviews with one of the directors, and informal meetings with other employees, a more detailed overview of topics to be discussed in the interviews was prepared. The information from the interviews was used in the succeeding interviews to refine the questions and to assess the validity of the statements between organizational levels and personnel. During this process the focus on digital technology became more tangible and the interviews and later analysis focused on the three elements of digitalization in integrated information systems, big data and machine learning. The focus on these three elements was thus not arrived at a priori; it was a result of the refinement of questions and conversations during the case study. In the case company the management accountants expressed that it was the integrated information systems that most directly affected their roles, while the other roles described how big data and machine learning have enabled them to take on new tasks.

The informal discussions provided valuable supplemental knowledge in addition to understanding of historical events in the company. The informal discussions at regional and head office premises revealed very few disagreements over the use of technology and the changes that were occurring in the company. The research question could have benefited from extending the period of interviews; however, documents from the company and associated organisations, including a confidential study from 2012 on the role of management accountants in the company, augmented the interviews. In addition it should be noted that several of the interview subjects held positions as divisional management accountants in InsuranceCo prior to their current positions.

The interviews were transcribed, coded and analysed using NVivo, a qualitative data analysis software package. The transcripts were coded based on practical constructs in the empirical material. The coding provided an overview of topics covered in the interviews, enabling analysis of the responses linking these topics to the theoretical constructs in the management accountant role literature.

\section{Case description}

\subsection{The finance sector in the Nordic countries}

The Nordic countries are among the richest and most digitalized countries in the world (European-Commission 2016; World Bank 2016). Their inhabitants are some 
of the most educated in the world, and the use of digital tools has had an impact on all levels of society (European-Commission 2016; Jāhāna 2016). The finance sector in particular has seen significant effects of digitalization since this has contributed to significantly reducing the number of branches (Finans Norge 2018). Customers have become accustomed to using the Internet as the preferred channel when contacting finance institutions.

Over the last two decades, finance institutions have systematically worked to utilize technology to improve profitability and customer service. Governments have promoted technology use through requiring tax reporting and other public reporting to be delivered via digital portals or systems. Financial regulation of the sector via Solvency II has also promoted digital solutions (European Parliament 2009). This regulation drives the development of IT systems to become more integrated and provide information more automatically and frequently.

Most of the price paid for insurance covers the risk premium, which is costs that calculated as likely to occur during the duration of the insurance period. Regulation in the Nordic countries prevents insurance companies from pricing insurance lower than the expected cost of providing the insurance. Insurance companies can choose to hold the risk themselves or distribute the risk and cost by reinsuring parts of their portfolio to other insurance or reinsurance companies. The largest cost element of insurance - calculation of the probability of accidents and related costs - has always played an important role for insurance companies. Historically, this calculation of risk premiums has fallen under the jurisdiction of actuaries in insurance companies.

The other cost elements in insurance are related to administrative costs, cost of sales activities, organizational development, customer service, IT function and finance functions, and so forth. The sales channel and activities vary between companies, but they rely on their own sales personnel and sales through agents. One example is car dealerships offering insurance acting as agents for insurance companies. Another example is independent agents offering insurance products through agency agreements with an insurance company.

A particularly important group of agents is banks. Some banks have their own insurance company, while others partner with insurance companies to provide insurance under the brand of the bank. Alternatively, the bank can offer the products of the insurance company without any customization or branding of products. The larger insurance companies also have retail bank divisions offering banking services. The sectors of banking and insurance are thus closely related, and developments in either sector frequently influence the other.

\subsection{InsuranceCo}

InsuranceCo is an insurance company with more than 3000 employees, and has a history going back over 200 years. It was formed as a mutual fire insurance company to assist local insurance companies to share and distribute risk. The formation was a consequence of small local mutual fire insurance companies' realization that they could benefit financially from cooperation to handle large pay-outs if large fires occurred in their regions (Schneiberg 2002). InsuranceCo has always had a strong 


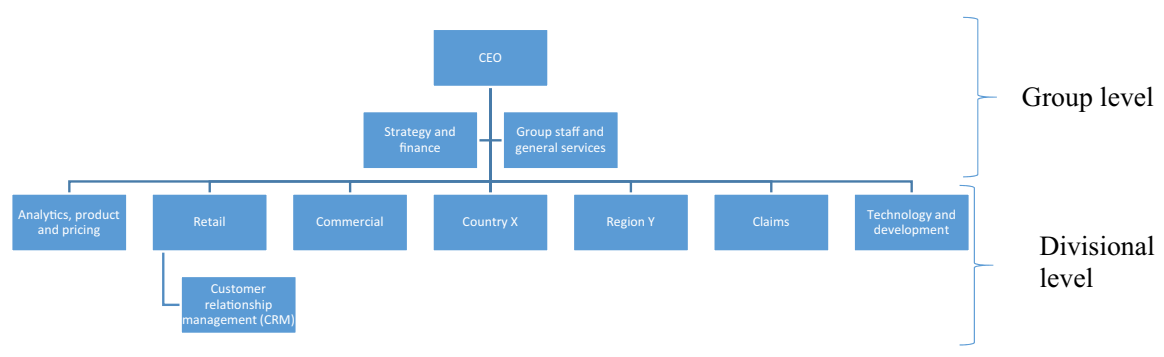

Fig. 1 InsuranceCo organizational chart

influence on coordinating activities, such as pricing products, and has provided shared services related to financial accounting to independent insurance companies. Today, InsuranceCo differs compared to the original entity. It now operates its own offices and agents and is no longer merely an administrative body for risk and profit sharing. InsuranceCo is the dominant entity among its agents and the remaining local insurance companies, setting strategy and defining financial and operational targets.

InsuranceCo has a strong presence in its home country, with several offices, some of which are fully owned while others are independent local insurance companies. International operations are slightly smaller than domestic operations in terms of the number of employees and revenue. Retail banking and pension savings represent a small proportion of turnover and number of employees compared to the insurance part of the company. Banking and pension savings have, however, been growing in recent years. Retail insurance in the home market is the largest division, while international operations are based in country or regional divisions (Fig. 1).

\subsection{Introduction and use of big data and machine learning in InsuranceCo}

Big data has been introduced over the last few decades in InsuranceCo as new and more advanced IT systems have been implemented. The new IT systems produce and store large amounts of data. The data have grown not only in volume, but also in variety and frequency. New systems in the company, such as phone systems, websites and claims systems, have increased the amount of internally available data. External information has also increased through access to data from public registries, third-party data providers and social media platforms. The replacement and upgrading of IT systems have enabled more frequent updates of data, improved transfer of data between systems and enabled easier access to data.

Analytical use of the data has increased as the volume, frequency and variety of data have enabled new possibilities for analyses. InsuranceCo has focused on becoming an analytics-driven company and aims to intelligently use data and analyses to utilize resources effectively and efficiently. In practice, this has resulted in increased integration between IT systems and the application of machine learning to various degrees in InsuranceCo. 
InsuranceCo does not appear to have had a clear plan for how the IT systems and their data could contribute to creating a more holistic IT system or data warehouse for the organization. Rather, the directors of the divisions had separate ideas for which systems and data would be useful for their own division. This has created a myriad of professional IT systems and data in the organization, combined with the IT systems from acquired companies that often continue to use parts of their existing infrastructure.

Integrated data in the case of InsuranceCo is when the data flows between information systems at specified frequencies. Flows are either unidirectional, for extracting data, or bidirectional, for extracting and inputting data into an IT system. Consequently, InsuranceCo has several systems to support the creation of information from IT systems. It has an internal data warehouse built on a SharePoint platform; it also has SAS Visual Analytics (SAS VA) and Oracle Hyperion financial management and planning. The systems overlap in providing the same data on several elements. The software, however, relies on the same data sources for collecting the overlapping data. The Oracle Hyperion software assists in budgeting, planning and performance measurement. The data warehouse distributes information to internal users. SAS VA is used for gathering a large, detailed dataset from the professional systems and external sources for the analysts for statistical modelling and data science.

The implementation of big data and machine learning has contributed to three changes in InsuranceCo. These changes serve as a backdrop for the observed changes in management accountant roles. First, InsuranceCo has access to digitalized customer information, which enables the company to cross-reference customer details internally and externally. External details from partners such as labour unions or customer programmes provide valuable insight into the price sensitivity and risk profile of customers. Second, information about competitors, the use of distribution channels (Internet, phone, offices) and customer behaviour data from the Internet or mobile activity provide new information. InsuranceCo can obtain an overview of competitors in the market by tracking customers' online activity or via the purchase of external datasets. To some extent, the company can store information on competitors' pricing by purchasing datasets and internal data from customers who want InsuranceCo to match offers from competitors. Third, the information can be aggregated and combined across departments and divisions, providing new sets of information, extending and going beyond the previous information available to InsuranceCo. This enables analyses to be more detailed and to provide information on new dimensions that were previously unaccounted for.

\subsection{The roles of management accountants in InsuranceCo}

Management accountants have become more business oriented in recent decades in InsuranceCo, with the aim of assisting and interacting with managers and decision-makers to gain an understanding of the financial impacts of decisions, in both the long and short term, and taking on a proactive business-oriented role. However, the reorientation of the role to become more forward looking has 
to some extent been dependent on the individual management accountant. Consequently, not all decision makers share the impression of management accountants becoming more business oriented and forward looking.

More recently, the number of management accountants has been reduced in InsuranceCo. Although difficult to quantify, as job titles vary between divisions and departments, there is a general impression that the number of management accountants has been significantly reduced in recent years:

We have tried it ourselves [to assess the number of management accountants], it is kind of hard when we look at titles. However, we have done some reorganizing projects, to look at staff and business support, including management accounting, so it is possible to do the exercise. We have done it many times, and it has been built down quite significantly. (Manager, planning and forecasting)

The number of management accountants has been reduced across all levels, from top-level group management accountants to divisional and departmental management accountants. Most notable, however, is the change at the divisional and department levels:

It might be primarily in the distribution units that it has been built down, for example the retail division does not have as many resources [management accountants] now versus previously. (Manager, planning and forecasting)

Contributing to the reduction of management accountants is the ability of decision makers to access information directly without the use of management accountants. This was illustrated in an interview with the director of sales in the retail division:

Director: Yes, there are [fewer management accountants]. However, you can say, I do more myself now.

Interviewer: More than previously?

Director: Yes, I dare to say so. I got more reports on my desk previously. When it comes to the most obvious thing to keep control of when you are managing, when you are in control of such a large business, is that the costs do not run wild. That is very doable, just enter [the IT system]. You know the date when the reports will be in the system, and just go in and check, and drill your way down [from divisional cost levels to regions, and the individual postings on each account for each region or branch].

In the largest division of InsuranceCo, with more than 1000 employees, there are currently only two employees with roles as management accountants. The decision makers below the divisional top management team, such as department heads, office managers, team leaders and others, do not get much time for business partnering with the management accountants due to the reduction in numbers thereof. 


\subsubsection{Changes towards specialization}

The increased sophistication of pricing models and use of various data sources and types contributes to specialization in the pricing process of InsuranceCo. Combined with increased use of data programming in $\mathrm{R}$ and Python, this development continues to maintain and potentially contribute to furthering the distance between analysts in the pricing and product division and management accountants in the finance function:

It is clear that a classic finance function, in my view, does not have the model skills needed to survive today. At least as we see it, one thing is to press F3, and skip through a GLM [generalized linear model] and implement it. There are some methodological considerations that are heavier than that. I am a graduate in business and administration, I'm a bad analyst, a leader with some visions and ideas. But the subject itself, the professional considerations is something I should keep away from, in my view, should certainly not mess too much with it either. (Director, pricing)

Previously, pricing analysis and implementation were challenging and demanding to perform, and it was not considered feasible to update daily in InsuranceCo. The stored customer data and product data have become more detailed in the IT systems, more frequently updated, and integrated with the internal systems of InsuranceCo, contributing to enabling the Analytics, Product and price division to find new ways of working. The opportunities that arise from linking the data and the information systems are challenging to explain, as the following quotation illustrates:

Does one really understand? What the possibilities are and what... a cool example then. We are talking about the fact that we need to get a report platform, and there is an employee coming to me saying, now I'll show you something cool. Then he has taken Flask, visualization for Python, and he can show me the optimization factors in geographical area and the given tariff in it. And he can bring up the factors, then he can change them, and he can simulate the effect of the change, and he can push it back to the pricing engine from a single screen. That process usually takes three weeks and involves five people and 10 systems. It is so damn powerful, and I did not know that it was that powerful. That is me in my department, imagine two levels up in the organization, they have no idea. (Director, pricing)

In InsuranceCo, technology has enabled the level of analysis of products and pricing to become more refined and frequently updated to reflect changes in the underlying data. Similarly, customer information and preferences have become digitalized in recent years, contributing to the transfer of previous local knowledge held by sales divisions to more perceived explicit knowledge in the Analytics, Product and price division. This transformation of information from local to explicit data is in line with previous research on integrated information systems (Chapman and Kihn 2009). The information on customer preferences, price 
sensitivity and how likely the customer is to accept an offer from a competitor is not only transformed from local tacit knowledge to more explicit data points; the use of big data and machine learning enables new ways of analysing the information. Grouping customers into small subsets of characteristics, extracting data such as their leisure activities, travel activity, memberships and location of properties, is perceived to provide new and reliable information on price sensitivity and behaviour. In InsuranceCo information from the data-driven approach is perceived to surpass that from local sales representatives on customer price sensitivity and behaviour. The Analytics, Product and price division and the Customer Relationships Management (CRM) department have become more sophisticated in how they use data and computer power to model the pricing elements and customer behaviour:

You can think of car insurance consisting of glass, rescue and liability and so forth, today we model on the low level [calculating a premium for each individual element]. Each of the elements and the models might well be quite different. Then we model frequency and consistency individually, and then we connect it to an actuary cost. So, you get a forest of models, and that [this way of modelling] might not be the only truth [interpretation of the data]. (Director, pricing)

Another example of changes in the role of management accountants relates to technology and can be illustrated with reference to interactions with CRM. The department analyses customers with the aim of identifying current customers who are liable to change to a different insurance company. It also analyses potential customers who could become customers of InsuranceCo if approached, and the likelihood that customers will buy additional products. Their analysis is based on large internal datasets of customer behaviour compiled over several years, combined with datasets from other internal and external providers. By using big data and machine learning, the CRM department is able to predict individual customer behaviour and prescribe recommended advice for the sales personnel, displayed on the screen of the insurance advisors and sales personnel as they are in contact with the individual customer.

Prior to the use of big data and machine learning, the individual sales personnel called who they felt were the best customers to contact, either to ensure that these customers did not leave the company or to attract new customers. The procedure for selecting customers and completing calls and meetings with them was largely up to the individual sales consultants. Gradually, the call list for sales personnel has become the responsibility of the CRM department. Currently, the sales personnel are required not to call or contact customers other than those on the list assigned by the CRM department:

It's just because it will give more value to control it intelligently [using all available data and machine learning], because the customer manager out there does not have all the information. They do not know the lifetime values of these products, they do not know about the competitor, if the customer only says that the competitor is much cheaper, or if they have really 
decided for [the offer from] InsuranceCo, and then they get an additional $10 \%$ discount. They do not know how price sensitive that customer is, or the type of customer. (Director, CRM)

More recently, the CRM department has also begun to monitor the effects of participating in fairs and events. It has consequently taken on responsibility for deciding which events to attend and how many personnel to assign to stands. There is naturally discussion between sales managers and the CRM department. However, as the CRM department uses machine learning and big data, comprising both internal and external data, the sales managers appear to comply with recommendations from the CRM department without significant resistance:

Part of the activity in the [local] offices is to attend on stands, fairs and similar. It was probably more up to the individual previously, now we have a purely analytical approach. If CRM says it is not profitable for us to attend a housing fair, then we do not attend the housing fair anymore. If CRM says we should use the power to support sponsorships then we'll do it, it's not up to each individual [managers and sales staff]. (Director, Sales)

This illustrates that a number of customer handling tasks have become specialized at the divisional level. Even for the group-level management accountants, there are indications that the tasks they perform have tended to become more specialized:

I usually say that at least $60 \%$ [of the group management accountants] work fairly technically, focusing on systems and reconciliation of data, etc., and then the rest are making some sensible analyses, and of course working a lot together with the business areas. (Management accountant at group level)

As tasks have become automated, the importance of specialized technical roles has been highlighted when integrations between information systems fails. Changes in one of the many systems or programs can influence other information systems.

We got ourselves a big surprise. In one of our processes, in property, we have automated payments to our suppliers, when they provide upfront estimated invoices [purchase order details]. Then you get the final invoice and it actually matches the invoice with the loss assessment. If there are deviations it goes to manual control, and if [it] matches it pays out. Within certain percentage and absolute sums. Then all of a sudden it ran wild, and we quickly saw that in our systems. What was it really that had happened? What it did was that it paid, it created double entries in our systems, in the financial systems, so no transfers were made to the customer. Customers got the right amount, but we got a double booking. And then suddenly one of the property products goes completely crazy. Then it started to become really stressful, is there something we've done wrong? Or is there something wrong with the terms? So, we dug deep into this. Then they found out, oh no. This is a system that has run wild, or it has been configured incorrectly. (SVP, Retail) 
The respondents reported that they do not feel they have enough time to get involved in other areas outside of their specialization, which is to offer support to managers, directors and other management accountants in obtaining decision data:

The technical part on how to connect to an external data source, to collect data from a cube [section of databases]. Very few [decision-makers and management accountants] get it, have experience, or even know about it. You just need a solution like Smart View [Hyperion-related add-in for Excel]. ... You must be, I would not call it an advanced user, but intermediate, it does not require too much. About a month ago, I helped one of the directors in division Z. You press here, and then there, and then there, and voilà. "There is the data that I manually punched for hours on Sunday" [quoting the director]. It [the level of knowledge] just sounds silly. (Management accountant, group level)

The use of big data in the Analytics, Product and price division and CRM requires skills and knowledge beyond a traditional finance function and the traditional role of management accountants, according to the respondents. This contributes to new, specialized roles in InsuranceCo, which take on responsibility for accounting for customer profitability and segmentation. Management accountants have historically not played an important role in pricing products in InsuranceCo. However, the divide between Analytics, Product and price and management accounting is described as increasing, contributing to a further specialization of roles in the company.

\subsubsection{Increasing divergence between divisional and group-level roles and identities}

The shift in accountability for customer selection and pricing has facilitated specialized positions higher in the organizational hierarchy; consequently, the decisionmaking processes have become increasingly centralized in InsuranceCo. The ability for individual managers or personnel to identify customers, select which products to offer and make discretionary adjustments has been significantly reduced in InsuranceCo. The customer and pricing models at the group level limit the boundaries for discretionary decisions in the divisional levels of the organization.

Concerning the roles of management accountants, the centralization of decisions creates some ambiguity depending on where the accountants are located in the organizational structure. Those in higher levels of the organization might become more involved in business-oriented activities through interdisciplinary projects. However, management accountants in the divisions can be viewed as reverting to a more traditional measurement role, distanced from the business orientation of group-level management accountants. The divisional management accountants' local knowledge and interpretation are to some extent replaced by big data, algorithms and machine learning, controlled at the group level. As the pricing models are improved, the autonomy for the division and individual sales managers to give discounts is significantly reduced for some products. Further, the use of customer analytics by the CRM department dictates, to an increasing degree, the number of staff needed to serve customers, and which customers they should serve, thereby reducing the ability of the divisional management accountants to influence the underlying business of the division. 
The divisional management accountants are responsible for reporting requested data to the group level and for controlling administrative expenses, such as ensuring that the regional offices do not overspend on office supplies or other local items. However, they are also involved in business projects related to improving routines and procedures in the divisions, although the possibilities for making independent discretionary judgements is limited, according to management accountants at the divisional level:

Now you're touching on a sensitive topic for me. We cannot [make] independent decisions on these topics since the agenda is decided on a group level [by other departments and divisions]. Concerning operations and optimizing our operational model in the division, of course we make independent decisions. But since so much of the agenda in the corporation is driven by systems, development, new projects, and profitability discussions... this becomes..., we just can't make independent decisions on these topics.

One director specifically mentioned that InsuranceCo had lost management accountants. As the remaining tasks often become repetitive and dull for management accountants, they end up applying for more stimulating positions outside InsuranceCo:

Director: I cannot..., we have too many good people leaving, those who end up making the stupid lists [copied and pasted from systems into Excel or a master system]. So that's not okay, especially when we have a stated goal of hiring and [retaining] them.

Interviewer: Is this a problem as you see it?

Director: It is not massive, but it is enough of the best people to make it a problem.

Divisional management accountants expected to serve and provide information to the specialized roles. By facilitating collection of data the management accountants are expected to contribute to support analyses for specialists in central departments of the organization. As expressed by a divisional management accountant:

So it's like...it becomes like, my role is to constantly make sure that CRM has the prerequisites they need to optimize value creation. Because then they can monitor and measure the effects of all the activities we have.

Management accountants at the higher level of the organization experience a higher degree of business involvement and trust from their superiors in pursuing projects:

I feel we've always been free, but we might have gained more trust, or... Now we see more problems, so we look more into issues than others did previously. So, we have the ability to be on the ball more frequently. (Manager, performance) 
The group-level management accountants do have more business involvement. They not only provide information to the top management team and directors but are asked for and provide advice to them. The information that the group-level management accountants provide is more detailed as a consequence of the integrated information systems and data warehouse, with more details than historically. Additionally, they describe having an overview of informal information in the organization, which they provide to decision makers. Consequently, the group-level management accountants can be described as having a business-oriented or hybrid role in which they play a more active part in decision-making. The divisions are expected to adhere to these central decisions, as indicated in the interviews:

CRM director: Something that has gone the other way [as opposed to centralization]? Very good question... yes, it is, for third-party channels, where you have different negotiating power. It all depends on how big our partner is, how global it is; of course, we are partnering with Google and we will be more precise in the customer journey that Google can make available to us...

Interviewer: What about internally in the organization?

CRM director: Yes, so they get access to a lot more of the intelligence, because they go into the CRM system and get the next best advice, the customer you should sell it to, what you should ask for and what you should take care of. That's it, that is moving it out. But it is still us who decides [who and] what to talk about then, so in reality it is limiting [and centralizing].

\subsection{New roles in InsuranceCo}

Another change in the role of the management accountants pertains to their job title. Only two of the respondents clearly identified with the management accountant or controller job title. Other respondents had more specialized responsibilities related to pricing, modelling or customer analysis, or to business development and provision of information; they did not belong to the finance function under the chief finance officer (CFO) in InsuranceCo. The tasks they perform are all relevant to management accounting; however, they are not performed by employees who identify as management accountants.

The insurance business has always employed statisticians and actuaries to calculate risk premiums for its products. With the focus on becoming an analytical company, InsuranceCo has increased the relative number of highly educated physicists, engineers, statisticians and mathematicians. In InsuranceCo new roles have moved closer to tasks that have historically been performed by managers. One case that illustrates this is found in claims handling, where big data and machine learning are applied to detect fraud and to speed up internal processes. Consequently, the number of employees working with claims handling has decreased in InsuranceCo in recent years:

When we set systems online, and when we first start to automate, the monitoring and control processes related to it, then we get really involved. And 
[we] might even take on the role of claims handlers or managers held [by] the claims departments previously. Like samples, for example previously $5 \%$ of claims [were] selected for manual control; now we control them through the system [automatically] and monitoring of the system. (Analyst)

The increased use of interdisciplinary teams has extended expectations to business-oriented roles, linking technological development to business processes and the ability to analyse information:

Those who get the combination of the operational processes, the business processes, the technology behind it, and are analytical and even a bit creative on the business development area, they are the winners in this race. It is a certain type of brains, and they are in short supply, so some become very expensive. Others become generalists, and they fall off the wagon. It is very much like that. It is perhaps what strikes me the most, that the competence requirements are completely different [compared to the past]. (Director, CRM)

As the physicists, engineers, mathematicians and statisticians take on managerial tasks based on their analytical competences and data access, it appears unlikely that InsuranceCo will resort to reports or analytical insights, other than financial insights, from management accountants. The access holders of these roles have to data can surpass that of management accountants, and the results from their operational analyses and calculations are likely to be just as valid as those provided by management accountants.

\section{Analysis}

\subsection{Digital technology as a contributor to specialized and narrow roles}

Digital technology has contributed to changes in InsuranceCo in a number of ways. Previous research has indicated expanding and broadening roles for management accountants as a potential effect of digital technology (Caglio 2003; Järvenpää 2007; Suddaby et al. 2015). However, nuancing previous research, the observations from InsuranceCo indicate that digital technology can contribute to specialized and narrow roles.

The case reveals that the use of digital technology to collect information, and to provide decision support, did not decentralize decisions in the company. Contrary to previous research (Dechow and Mouritsen 2005; Järvenpää 2007), the case provided observations and direct quotes from managers that revealed they considered it more sensible to control decisions centrally rather than distributing them. The description of how digital technology facilitated new specialist roles within CRM and the Analytics, Product and price division illustrate how tasks of customer accounting and pricing and product analyses can become highly specialized.

The access to information, most notably through integrated information systems, enables directors, managers and employees working with analyses to access information without the use of management accountants. In InsuranceCo, many of the 
integrations between systems enable automatic exchange of information, without any manual or human interaction involved. The specialists who monitor or oversee the flow of information between systems can be actuaries, physicists or management accountants. However, for management accountants the digital technology contributes to a new, narrow role as technical experts who oversee system integrations and information flows between systems.

In InsuranceCo, the technical management accountant role can entail acting as an expert on the digital planning and forecast system, Hyperion. The technical role ensures that the integrated information from sales and other professional systems is collected, processed and correctly presented in the Hyperion planning and forecast system. Information on the number of new insurance policies, the profitability of product lines, the various customer segments, the number of employees, and other indicators are integrated from the professional systems into the planning and forecasting platform by the technical role, and vice versa when performance and financial data are extracted from the planning and forecast system to the CRM system, SharePoint report platform, sales or other professional systems in the organization. The technical role is expected to provide the prerequisite information and assist in implementing and constantly monitoring the consistency of planning, performance and financial information between systems as these systems are updated, reconfigured or replaced. The role thus entails a narrow technical focus, as described by the respondents. This technical role appears to be distanced from decision making and corporate strategy in InsuranceCo.

However, the business-oriented management accountants at the group level of InsuranceCo expressed that they are expected to be freer and provide decision support in an expanding and broadening array of decisions and topics. The description of management accountant roles as complex and multi-layered (Byrne and Pierce 2007; Schaltegger and Zvezdov 2015) provides a refined perspective by which to analyse how digital technology contributes to changes in the role.

\subsection{Exploring the competition over jurisdiction}

The following section analyses the relationship between the role of management accountants and technological change. The analysis seeks to address the intraorganizational level of analysis, which has been identified as an under-researched area (Abbott 1988; Goretzki et al. 2013; Suddaby et al. 2015), as it aims to increase understanding of how groups and technologies can influence management accountant roles.

The management accountants in InsuranceCo face competition over jurisdiction from other groups of employees, particularly from the Analytics, Product and price division and CRM. For the largest retail division, groups of CRM employees claim jurisdiction in all tasks related to customer handling, whether it is customer acquisition, expected lifetime value, how to contact customers or which customers should be targeted. As the CRM employees present knowledge claims supported by big datasets on customer behaviour in combination with statistical knowledge and the 
use of machine learning to predict outcomes, the divisions and the divisional management accountants have relinquished their jurisdiction in this domain.

The changes in jurisdiction between management accountants and the CRM department result not in overt conflict but rather an acceptance of the strength of each group, corresponding to findings by Suddaby et al. (2015). Competition over jurisdiction was also observed between management accountants and the Analytics, Product and price division, where the Analytics, Product and price division claims expert knowledge of pricing and product specification. As with CRM, the Analytics, Product and price division presents knowledge claims supported by its insights derived from big datasets in combination with statistical knowledge and the use of machine learning to predict outcomes. However, the acceptance and agreement over jurisdiction do not expand the roles of accounting or of management accountants, as indicated by previous research (Burns and Baldvinsdottir 2005; Järvenpää 2007; Suddaby et al. 2015). The knowledge claims from the Analytics, Product and price division and CRM rather limit the boundaries of management accountants, as these groups, to a large extent, have autonomous control over the process and provision of information in their domains.

The knowledge of how to distribute costs across divisions and departments, and to assess the financial effects of decisions, remains within the jurisdiction of management accountants. Likewise, no other groups claim jurisdiction over financial planning; however, jurisdiction over performance measurement entails increasing competition as customer, pricing and product indicators are not disconnected from the influence of CRM and the Analytics, Product and price division.

\subsection{Changes in management accountant roles and identities}

This analysis of the changes in role and identity draws on Sveningsson and Alvesson (2003) description (p.1168-1169):

When we talk about role we focus more on generalized expectations of behaviour communicated in the environment rather than prescriptions for self-understanding, thus making a clear distinction between role and identity, although there is interplay between them.

The study finds that the changes in the roles of management accountants can be described as having followed two divergent paths depending on where the management accountant was positioned in the organizational hierarchy. Changes in expectations regarding behaviour have not been identical for the divisional management accountants and the group-level management accountants.

As the tasks of analysing customers, and monitoring, measuring and directing sales activity have been transferred to specialists in the CRM department, the influence of the divisional level of the organization on these topics has been reduced. The directors or managers in the retail division expressed trust in the insights and validity of analyses presented by the CRM department, and the retail division obediently adheres to these analyses. Discussions may arise between the parties, but the 
power of and trust in statistical analysis and big data remains largely uncontested throughout the organization.

Pricing models have always been, and remain, the domain of actuaries in InsuranceCo. However, the divisions' ability to make discretionary decisions through discounts and deviations from pricing models has been reduced. The integrated information systems and big data enables the Analytics, Product and price division to collect more detailed and updated price information and incorporate this information into their models. The task of monitoring discretionary judgements has thus been reduced at the divisional level, and the information has to a large extent has become transparent for the Analytics, Product and price division through the access to more detailed data from the divisions. More frequent discussions take place between the divisions and Analytics, Product and price employees than between the divisions and the CRM department, and these discussions are often related to disagreements regarding market understanding of terms and the price elasticity of customer segments. However, the trust in statistical analysis and big data generally remains secure on the part of both parties.

As the CRM department and the Analytics, Product and price division have assimilated tasks in the domains of pricing, and customer analysis and operations, expectations of the behaviour of the divisions and the divisional management accountants have changed. As described above, the retail division does not question analyses directing their operational attention to sponsorships at the expense of attention to housing fairs. The retail division respects the statistical analyses and implements operational changes indicated thereby. For pricing tasks, the Analytics, Product and price division applies pricing models across all divisions and as the division is not necessarily familiar with all products, the price of similar products or pricing elements of products can be switched during analyses. The other divisions are expected to identify and comment on direct errors in pricing models. However, the empirical data indicate that the divisions do not contest the statistical analyses, data or models unless there are clear errors in the datasets.

The role of the divisional management accountants has thus narrowed rather than broadened. Not only have the tasks become narrower, the expected behaviour patterns indicate that management accountants are to adhere to analyses from higher organizational levels. While the interviews focused on the management accountants' roles, the interviews provided indications that role changes could contribute to sensitive and soar identity conflicts at the individual level of the divisional management accountants. And examples were given of these employees leaving the company to find more stimulating positions. This indicates that they were subject not only to role changes but that role changes contributed to identity conflict (Brown 2019; Horton and Wanderley 2018).

For the group-level management accountants the integrated information systems and big data have facilitated automating the tasks of data collection and accessing more detailed information across the organization. This has contributed to some of the group-level management accountants becoming more specialized in the information systems and performing what can be described as a digital technical specialist role, combing what has been described as methodological and information specialists roles with digital technology (Byrne and Pierce 2007; Rieg 2018; Schaltegger 
and Zvezdov 2015). For the non-technical group-level management accountant roles expectations of their behaviour have changed and contributed to allowing them to operate more freely and get involved in business decisions, corresponding to a business-oriented partner role for decision makers. The access to detailed and updated information from the divisions has supported the legitimization of group-level management accountants as holding a business partner role in InsuranceCo. The study did not find any indications of identity conflicts among the business-oriented grouplevel management accountants. They expressed alignment between their roles in terms of their freedom and their ability to pursue topics that are of interest to them.

\section{Discussion}

The findings illustrate that the roles of management accountants are changing in InsuranceCo, and digital technology in the form of big data, machine learning, and integrated information systems contributes to facilitating these changes. The analysis reveals four main findings.

First, digital technology has contributed to several changes in the roles of management accountants. The literature has focused on the expanding and broadening roles (Burns and Baldvinsdottir 2005; Järvenpää 2007) experienced by businessoriented management accountants; however, the case illustrates how digital technology can contribute to creating narrower and more specialized roles for management accountants.

Second, by analysing the changes through a perspective of professional jurisdiction competition (Abbott 1988), the study finds that claims of expert knowledge by actuaries, mathematicians, physicians and statisticians can limit the boundaries of management accountants' roles. The intra-organizational level of analysis, in which internal groups compete over jurisdiction (Abbott 1988; Goretzki et al. 2013), enables a broader perspective by which to analyse how digital technology contributes to interactive changes in roles and influence within organizations.

Third, digital technology does not simply influence the roles of management accountants through changes in tasks. Tasks can be important elements of behaviour patterns; however, the case indicates that the broader social contexts in which the expected behavioural patterns change (Biddle 1986; Sveningsson and Alvesson 2003) influence the relationship between digital technology and roles. The reduced expectations, and changes in behaviour, of divisional management accountants to participate in customer and pricing discussions in the case illustrate how expectations of behaviour can contribute to changes in roles.

Fourth, the changes that digital technology contributes to in the roles of management accountants can mediate the identity-work of the individual management accountants (Brown 2015; Goretzki and Messner 2019; Järventie-Thesleff and Tienari 2016). Either as the technology contributes to autonomous and free roles where the management accountant can pursue topics of interest linked to the identity of how the individual management accountant see themselves, akin to a dream come true for the management accountant. Or digital technology can contribute to roles with reduced influence, repetitive tasks and endless provisioning of requested 
information to competing specialist roles. Thus, digital technology can influence individuals to see their roles as disconnected from their identity and appearing as nightmares. The empirical descriptions, indicating that identity-conflicts can be sensitive and soar topics, provides a perspective to understand how individual management accountants can find remedy in pursuing other roles closer aligned to their identity. However, it is important to underline that this is not causal interpretation of how a technology impact management accountants' roles and identity. Digital technology can facilitate, influence or contribute to changes in the roles and identitywork of management accountants. However, more research is needed to improve the knowledge of how digital technology influence the roles and identities of management accountants.

The relationship between digital technology and changes in the roles and jurisdiction of management accountants is complex. As a single case study the generalizability of this paper's findings to other industries and organizations is limited; however, for finance industry organizations pursuing strategies by which to become data or analytics driven the findings might hold some generalizability. While this explorative study focused on describing how digital technology contributed to changes in a single company, further studies in other industries and regions can provide insights to increase our understanding of the relationship between digital technology and the role of management accountants.

\section{Conclusion}

This paper has empirically explored how digital technology (integrated information systems, big data and machine learning) contributes to changes in the roles, identities and jurisdiction of management accountants in InsuranceCo, a Nordic insurance company. The findings reveal that digital technology contributes to changes in the roles and identities of management accountants heterogeneously as professions compete (Abbott 1988) for tasks and influence on the boundaries of management accountant roles. Analysing roles as expected behavioural patterns (Sveningsson and Alvesson 2003) enables more fine-grained theorizing of the relationship between digital technology and management accountant roles. Organizations that implement digital technologies, as well as researchers, might benefit from analysing how digital technology can influence expected behaviour patterns in organizations and potentially contribute to triggering competition between professions.

Acknowledgements Open Access funding provided by NTNU Norwegian University of Science and Technology (incl St. Olavs Hospital - Trondheim University Hospital). This paper has greatly benefited from comments from two anonymous reviewers; participants at the EAA 2019 conference; ACMAR doctoral colloquium 2018; NTNU Business School Conference of 2018; and colleagues at the Norwegian University of Science and Technology.

Open Access This article is licensed under a Creative Commons Attribution 4.0 International License, which permits use, sharing, adaptation, distribution and reproduction in any medium or format, as long as you give appropriate credit to the original author(s) and the source, provide a link to the Creative Commons licence, and indicate if changes were made. The images or other third party material in this article 


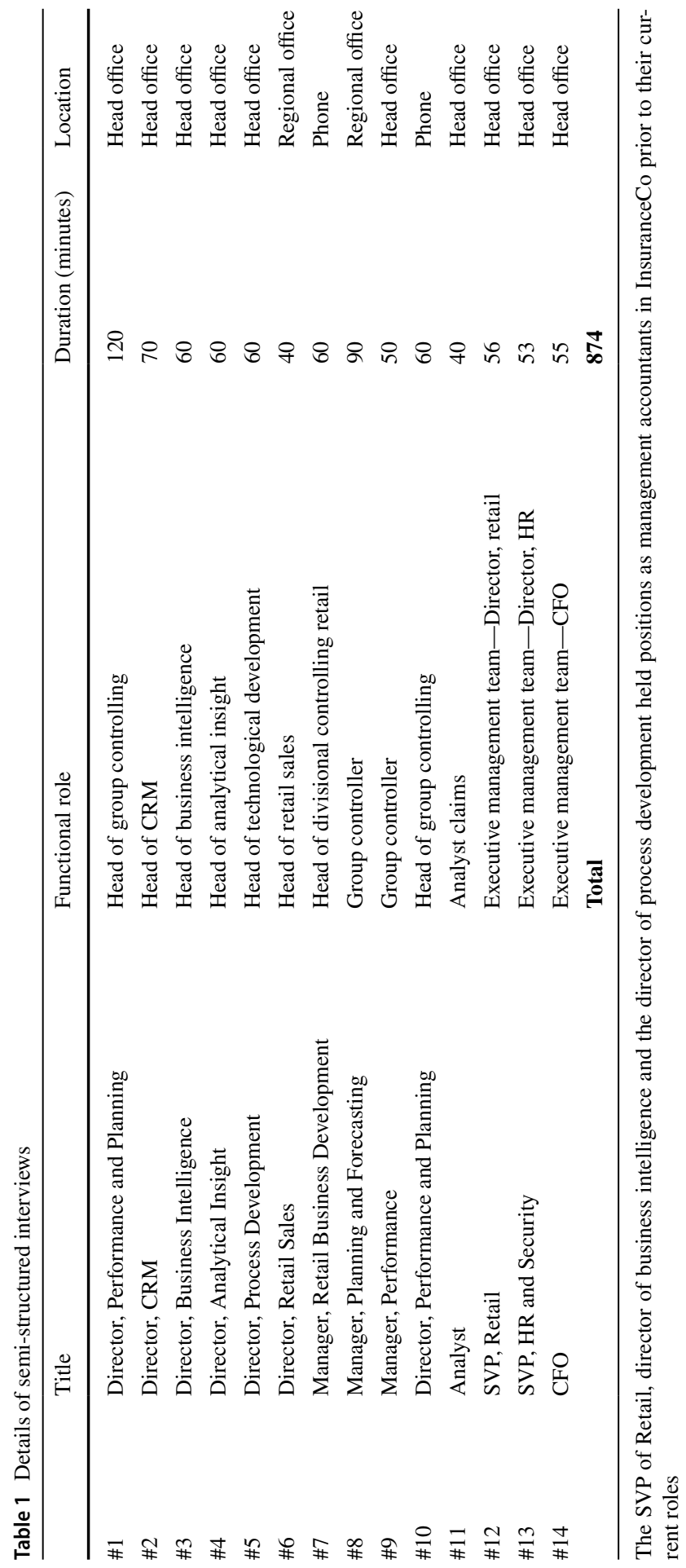


are included in the article's Creative Commons licence, unless indicated otherwise in a credit line to the material. If material is not included in the article's Creative Commons licence and your intended use is not permitted by statutory regulation or exceeds the permitted use, you will need to obtain permission directly from the copyright holder. To view a copy of this licence, visit http://creativecommons.org/licen ses/by/4.0/.

\section{Appendix 1}

See Table 1.

\section{References}

Abbott, A. (1988). The system of professions: An essay on the division of expert labor. Chicago, IL: University of Chicago Press.

Accenture (2018). CFO reimagned - From bottom line to front line. https://www.accenture.com/t2018 0910T083815Z_w__us-en/_acnmedia/PDF-85/Accenture-CFO-Research-Global.pdf. Accessed 15.092018.

Ahrens, T., \& Chapman, C. S. (2006). Doing qualitative field research in management accounting: Positioning data to contribute to theory. Account Organizational Society, 31, 819-841. https://doi. org/10.1016/j.aos.2006.03.007.

Al-Htaybat, K., \& von Alberti-Alhtaybat, L. (2017). Big Data and corporate reporting: Impacts and paradoxes. Account Audit Accountability, 30, 850-873. https://doi.org/10.1108/Aaaj-07-2015-2139.

Alvesson, M., Lee Ashcraft, K., \& Thomas, R. (2008). Identity matters: Reflections on the construction of identity scholarship in organization studies. Organization, 15, 5-28. https://doi.org/10.1177/13505 08407084426 .

Appelbaum, D., Kogan, A., Vasarhelyi, M., \& Yan, Z. K. (2017). Impact of business analytics and enterprise systems on managerial accounting. International Journal of Accounting Information Systems, 25, 29-44. https://doi.org/10.1016/j.accinf.2017.03.003.

Bhimani, A., \& Willcocks, L. (2014). Digitisation, 'Big Data' and the transformation of accounting information. Accounting and Business Research, 44, 469-490. https://doi.org/10.1080/00014 788.2014.910051.

Biddle, B. J. (1986). Recent developments in role theory. Annual Review of Sociology, 12, 67-92.

Brown, A. D. (2015). Identities and identity work in organizations. International Journal of Management Reviews, 17, 20-40. https://doi.org/10.1111/ijmr.12035.

Brown, A. D. (2019). Identities in organization studies. Organizational Studies, 40, 7-22. https://doi. org/10.1177/0170840618765014.

Burns, J., \& Baldvinsdottir, G. (2005). An institutional perspective of and praxis. European Accounting Review, 14, 725-757. https://doi.org/10.1080/09638180500194171.

Byrne, S., \& Pierce, B. (2007). Towards a more comprehensive understanding of the roles of management accountants. European Accounting Review, 16, 469-498. https://doi.org/10.1080/0963818070 1507114.

Caglio, A. (2003). Enterprise Resource Planning systems and accountants: Towards hybridization? European Accounting Review, 12, 123-153. https://doi.org/10.1080/0963818031000087853.

Chapman, C. S., \& Kihn, L. A. (2009). Information system integration, enabling control and performance. Accounting, Organizations and Society, 34, 151-169. https://doi.org/10.1016/j.aos.2008.07.003.

Chenhall, R. H. (2003). Management control systems design within its organizational context: findings from contingency-based research and directions for the future Accounting. Organizations and Society, 28, 127-168. https://doi.org/10.1016/S0361-3682(01)00027-7.

Cooper, D. J., \& Robson, K. (2006). Accounting, professions and regulation: Locating the sites of professionalization. Accounting, Organizations and Society, 31, 415-444. https://doi.org/10.1016/j. aos.2006.03.003. 
Dechow, N., \& Mouritsen, J. (2005). Enterprise resource planning systems, management control and the quest for integration Accounting. Organizations and Society, 30, 691-733. https://doi.org/10.1016/j. aos.2004.11.004.

Eklund, S., Tam, M., Woodcock, E. (2018). New technology, new rules: Reimagining the modern finance workforce. Mckinsey. https://www.mckinsey.com/business-functions/operations/our-insights/newtechnology-new-rules-reimagining-the-modern-finance-workforce. Accessed 15.032019.

European Parliament (2009). Directive 2009/138/EC of the European Parliament and of the Council of 25 November 2009 on the taking-up and pursuit of the business of Insurance and Reinsurance (Solvency II).

European-Commission (2016). Europe's digital progress report. EU - European Comission. http:// ec.europa.eu/newsroom/dae/document.cfm?action=display\&doc_id=17338. Accessed 11.12 2016.

Finans Norge (2018). Antall ekspedisjonssteder. Finans Norge,. https://www.finansnorge.no/statistikk/ bank/antall-ekspedisjonssteder/. Accessed 15 Feb 2018.

Fine, G. A., \& Hallett, T. (2014). Group Cultures and the Everyday Life of Organizations: Interaction Orders and Meso-Analysis Organ Stud, 35, 1773-1792. https://doi.org/10.1177/017084061454615 3.

Frey, C. B., \& Osborne, M. A. (2017). The future of employment: How susceptible are jobs to computerisation? Technological Forecasting and Social Change, 114, 254-280. https://doi.org/10.1016/j.techf ore.2016.08.019.

Friedman, A. L., \& Lyne, S. R. (2001). The beancounter stereotype: towards a general model of stereotype generation. Critical Perspectives on Accounting, 12, 423-451. https://doi.org/10.1006/ cpac. 2000.0451 .

Gandomi, A., \& Haider, M. (2015). Beyond the hype: Big data concepts, methods, and analytics. International Journal of Information Management, 35, 137-144. https://doi.org/10.1016/j.ijinf omgt.2014.10.007.

Goretzki, L., Lukka, K., \& Messner, M. (2017). Controllers' use of informational tactics. Accounting and Business Research, 48, 700-726. https://doi.org/10.1080/00014788.2017.1407627.

Goretzki, L., \& Messner, M. (2019). Backstage and frontstage interactions in management accountants' identity work Accounting. Organizations and Society, 74, 1-20. https://doi.org/10.1016/j. aos.2018.09.001.

Goretzki, L., Strauss, E., \& Weber, J. (2013). An institutional perspective on the changes in management accountants' professional role. Management Accounting Research, 24, 41-63. https://doi. org/10.1016/j.mar.2012.11.002.

Granlund, M., \& Lukka, K. (1998). Towards increasing business orientation: Finnish management accountants in a changing cultural context. Management Accounting Research, 9, 185-211. https:// doi.org/10.1006/mare.1998.0076.

Granlund, M., \& Malmi, T. (2002). Moderate impact of ERPS on management accounting: a lag or permanent outcome? Management Accounting Research, 13, 299-321. https://doi.org/10.1006/ mare.2002.0189.

Holmgren Caicedo, M., Mårtensson, M., \& Tamm Hallström, K. (2018). The development of the management accountant's role revisited: An example from the Swedish Social Insurance Agency. Financial Accountability \& Management, 34, 240-251. https://doi.org/10.1111/faam.12156.

Horton, K. E., \& Wanderley, C. D. (2018). Identity conflict and the paradox of embedded agency in the management accounting profession: Adding a new piece to the theoretical jigsaw. Management Accounting Research, 38, 39-50. https://doi.org/10.1016/j.mar.2016.06.002.

Jāhāna, S. (2016). Human development report 2016: human development for everyone. New York: United Nations Publications.

James, G., Witten, D., Hastie, T., \& Tibshirani, R. (2013). An introduction to statistical learning (Vol. 112). New York: Springer.

Järvenpää, M. (2007). Making business partners: A case study on how management accounting culture was changed. European Accounting Review, 16, 99-142. https://doi.org/10.1080/096381807012659 03.

Järventie-Thesleff, R., \& Tienari, J. (2016). Roles as Mediators in Identity Work. Organization Studies, 37, 237-265. https://doi.org/10.1177/0170840615604500.

Johnson, H. T., \& Kaplan, R. S. (1986). Relevance lost: the rise and fall of management accounting. Boston, MA: Harvard Business Press. 
Kallunki, J.-P., Laitinen, E. K., \& Silvola, H. (2011). Impact of enterprise resource planning systems on management control systems and firm performance. International Journal of Accounting Information Systems, 12, 20-39. https://doi.org/10.1016/j.accinf.2010.02.001.

Kurunmäki, L. (2004). A hybrid profession-the acquisition of management accounting expertise by medical professionals Accounting. Organizations and Society, 29, 327-347. https://doi.org/10.1016/ s0361-3682(02)00069-7.

McAfee, A., \& Brynjolfsson, E. (2012). Big data: the management revolution. Harvard Business Review, 90, 61-68.

McCorkell, A., Shapiro E. (2016). Breaking away: How leading finance functions are redefining excellence. PwC. http://www.pwc.com/us/en/increasing-finance-function-effectiveness/finance-effectiven ess-benchmark-study.html. Accessed 04.052017.

Miller, P., \& Hopwood, A. G. (1994). Accounting as social and institutional practice: an introduction vol 1. Accounting as social and institutional practice (Vol. 98). Cambridge: Cambridge University Press.

Moll, J., \& Yigitbasioglu, O. (2019). The role of internet-related technologies in shaping the work of accountants: New directions for accounting research. The British Accounting Review. https://doi. org/10.1016/j.bar.2019.04.002.

Murphy, K. P. (2012). Machine learning: a probabilistic perspective. Cambridge: MIT press.

Orlikowski, W. J. (1992). The duality of technology: Rethinking the concept of technology in organizations. Organization Science, 3, 398-427.

Quattrone, P. (2016). Management accounting goes digital: Will the move make it wiser? Management Accounting Research, 31, 118-122. https://doi.org/10.1016/j.mar.2016.01.003.

Rieg, R. (2018). Tasks, interaction and role perception of management accountants: evidence from Germany. Journal of Management Control, 29, 183-220. https://doi.org/10.1007/s00187-018-0266-0.

Rikhardsson, P., \& Yigitbasioglu, O. (2018). Business intelligence \& analytics in management accounting research: Status and future focus. International Journal of Accounting Information Systems, 29, 37-58. https://doi.org/10.1016/j.accinf.2018.03.001.

Rom, A., \& Rohde, C. (2007). Management accounting and integrated information systems: A literature review. International Journal of Accounting Information Systems, 8, 40-68. https://doi. org/10.1016/j.accinf.2006.12.003.

Scapens, R., \& Jazayeri, M. (1998). SAP: Integrated information systems and the implications for management accountants. Management Accounting Magazine for Chartered Management Accountants, $76,46$.

Scapens, R. W., \& Jazayeri, M. (2003). ERP systems and management accounting change: opportunities or impacts? A research Note European Accounting Review, 12, 201-233. https://doi. org/10.1080/0963818031000087907.

Schäffer, U., \& Brückner, L. (2019). Rollenspezifische Kompetenzprofile für das. Controlling der Zukunft Controlling \& Management Review, 63, 14-31. https://doi.org/10.1007/s12176-019-0046-1.

Schaltegger, S., \& Zvezdov, D. (2015). Gatekeepers of sustainability information: exploring the roles of accountants. Journal of Accounting \& Organizational Change, 11, 333-361. https://doi. org/10.1108/jaoc-10-2013-0083.

Schneiberg, M. (2002). Organizational heterogeneity and the production of new forms: Politics, social movements and mutual companies in American fire insurance, 1900-1930. In M. Lounsbury \& M. Ventresca (Eds.), Social structure and organizations revisited (pp. 39-89). Bingley: Emerald Group Publishing Limited.

Simpson, B., \& Carroll, B. (2008). Re-viewing 'Role' in Processes of Identity Construction. Organization, 15, 29-50. https://doi.org/10.1177/1350508407084484.

Suddaby, R., Saxton, G. D., \& Gunz, S. (2015). Twittering change: The institutional work of domain change in accounting expertise. Accounting, Organizations and Society, 45, 52-68. https://doi. org/10.1016/j.aos.2015.07.002.

Sveningsson, S., \& Alvesson, M. (2003). Managing managerial identities: Organizational fragmentation, discourse and identity struggle. Human Relations, 56, 1163-1193. https://doi.org/10.1177/00187 267035610001.

Weber, J. (2011). The development of controller tasks: explaining the nature of controllership and its changes Journal of Management. Control, 22, 25-46. https://doi.org/10.1007/s00187-011-0123-x.

Wolf, S., Weißenberger, B. E., Claus Wehner, M., \& Kabst, R. (2015). Controllers as business partners in managerial decision-making. Journal of Accounting \& Organizational Change, 11, 24-46. https:// doi.org/10.1108/jaoc-10-2012-0100. 
World Bank. (2016). World Development Report 2016: Digital Dividends. World Bank, Washington DC. License: Creative Commons Attribution CC BY 3.0 IGO. https://doi.org/10.1596/978-1-4648-0671-1.

Publisher's Note Springer Nature remains neutral with regard to jurisdictional claims in published maps and institutional affiliations. 